\title{
Implementation of $100 \%$ Electric Vehicle in Bali with the Supply of Potential Independent Solar Energy
}

Sudarno Zensu

Department of Electrical Engineering Universitas Indonesia

Depok 16424, Indonesia sudarno81@ui.ac.id

Rinaldy Dalimi Department of Electrical Engineering Universitas Indonesia Depok 16424, Indonesia rinaldy@eng.ui.ac.id
Electrical vehicle is the future of transportation. This thesis is about how to transform the usage of fossil fuel vehicle to electrical vehicle in Bali. Bali is an island with the longest distance from one of its districts to Denpasar city is 95,6 km. This distance is reachable by the common electrical vehicle that available in the market now. The usage of the electrical vehicle requires good development and planning, otherwise it will cause problem for the electrical systems. The consumption of electrical energy will increase. In 2019, Bali used 5,908 GWh electricity in a year. And if all the 2 wheels and 4wheels vehicles now are electrical vehicle, it will require extra 2,823 GWh per year. It will impact the planning of power generation in Bali.Another challenge for the electrical systems is the duck curve problem. The habit of the user charges their vehicle will also impact the daily load curve of an electrical systems. If all the two wheels and four wheels vehicles now are electrical vehicle, and all users conduct the charging at the same time in 4 hours duration, the load will increase about 1,934 GW. The practical and applicable solution is the independent power producer concept by the solar PV. If every electric vehicle user installs the solar PV for their electrical vehicle consumption, this will solve all the problem.

Keywords: Electric Vehicle, Green Energy, Solar PV, Independent Power Producer, Load Forecasting

\section{INTRODUCTION}

Electric vehicle is the future of land transportation, it is currently the most promising technology [1]. Bali is one of an Island in Indonesia that suitable to start implement electric vehicle, by its geography and the tourisms aspect. Bali is an Island of 5,780 kilo meter square. Bali has nine districts, and Denpasar as the city or capital. The farthest district to Denpasar is 95.16 kilo meter. See table 1 for the distance every district to Denpasar city.

Table 1: Bali district area and distance to Denpasar [2]

\begin{tabular}{ccc}
\hline District/City & $\begin{array}{c}\text { Distance to } \\
\text { Denpasar }(\mathbf{k m})\end{array}$ & Area $\left.\mathbf{k m}^{\mathbf{2}}\right)$ \\
\hline Jembrana & 95.16 & 848.80 \\
\hline Tabanan & 20.88 & $1,013.88$ \\
\hline Badung & 6.50 & 418.62 \\
\hline Gianyar & 26.73 & 368.00 \\
\hline Klungkung & 39.70 & 315.00 \\
\hline Bangli & 41.39 & 490.71 \\
\hline Karangasem & 77.60 & 839.54 \\
\hline Buleleng & 78.00 & $1,364.73$ \\
\hline
\end{tabular}




\begin{tabular}{ccc}
\hline District/City & $\begin{array}{c}\text { Distance to } \\
\text { Denpasar } \mathbf{( k m )}\end{array}$ & Area $\left.\mathbf{( k m}^{\mathbf{2}}\right)$ \\
\hline Denpasar & 0.00 & 127.78 \\
\hline Total & & $5,780.06$ \\
\hline
\end{tabular}

Bali has 4.3 million populations, and about $50 \%$ of the populations stay in Badung, Gianyar and Denpasar. So, most of the activity of $50 \%$ of the population are in these three districts. It is reflected from most of tourism activities and the hotels in Bali are in that area. The distance from Badung and Gianyar to Denpasar is only 6.5 and $26.73 \mathrm{~km}$. It is reachable by using the electric vehicle that available in the market. Based on the data from Table 1 and Figure 1, we can state that Bali is ideal area to implement or start using the vehicle car. It is aligned with what Indonesia government had promoted during the APEC conference in 2013. Indonesia government promoted green energy concept and use the electric car. A charging station had been built near the conference are at that time.

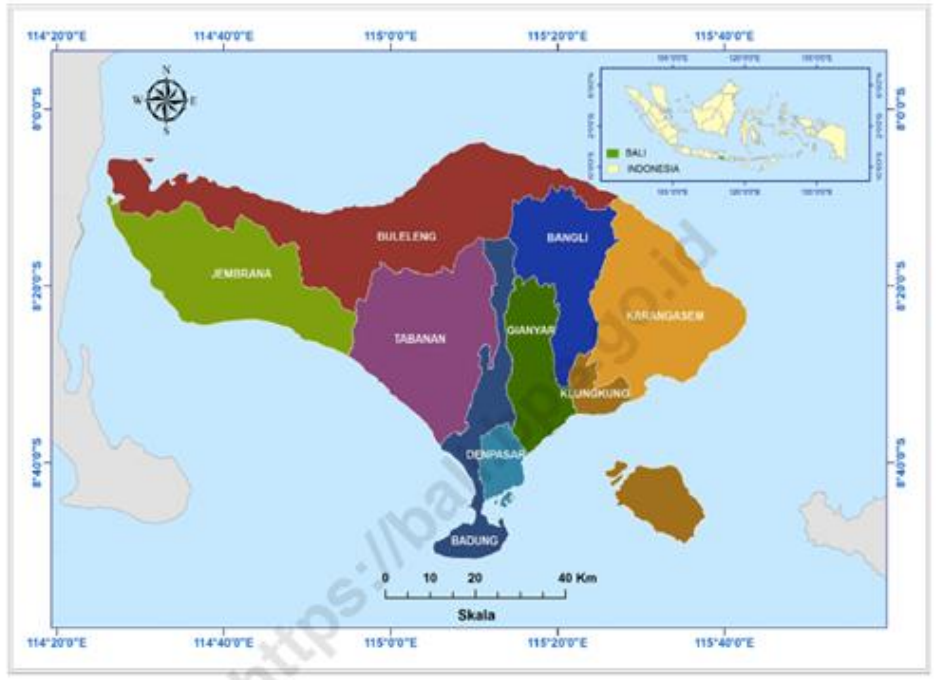

Figure 1: Bali Island district [2]

Sooner or later the fossil fuel vehicle will be change by the electric vehicle [3]. The electric systems need to be ready to support the usage of electrical energy. Bali island electric system has the peak load about 966 MW with $78.92 \%$ load factor in 2019 before the covid-19 pandemic. The electrical systems need to be ready for capacity increase needed to support electric vehicle. A forecast or calculation need to be done for the planning. Electric vehicle will need big numbers of electricity [4-6]. Another problem also the habit of electric vehicle user on charging the electric vehicle will impact the load curve. The power factor in Bali now is about $78.92 \%$ [7]. If the electric vehicles users charge in the same time, it will make a duck curve in the systems. And it will become a problem for the systems to be efficient. Analysis and planning should be well worked out. In Figure 3, we can see the load curve on January 29th, 2021. The peak load was 980 MW at 7-8 pm.

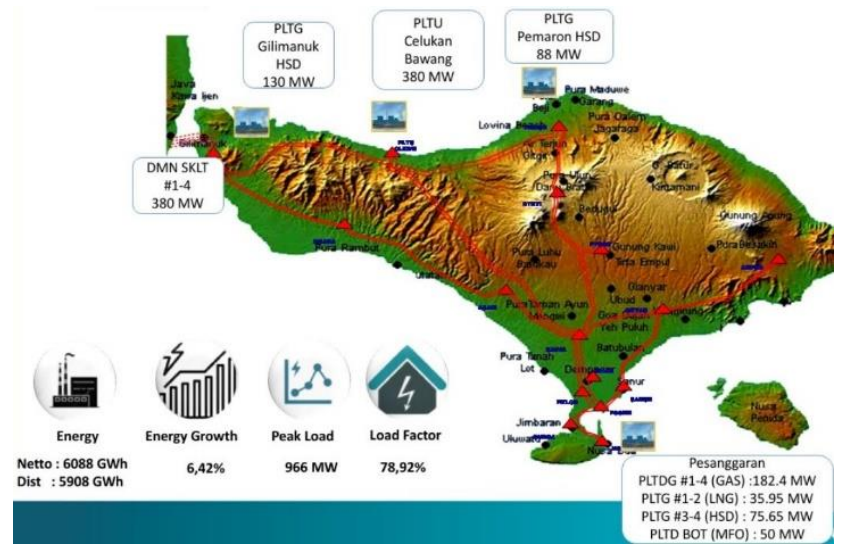

Figure 2: Bali 2019 electricity data 


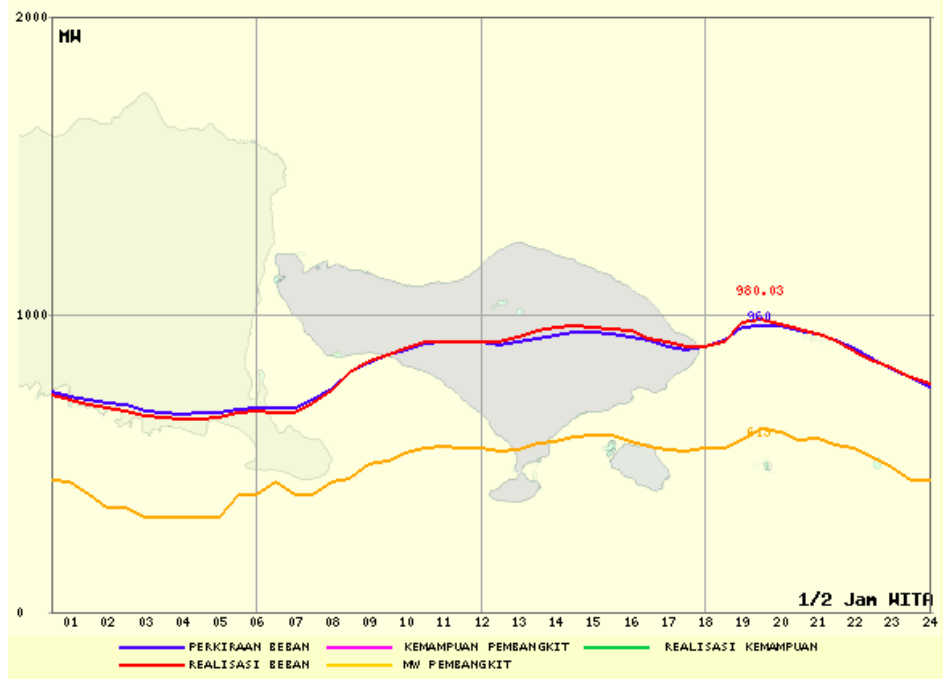

Figure 3: Load curve of bali island

\section{RESEARCH METHODOLOGY}

This research will calculate the energy needed if all the conventional two wheels and four wheels vehicles in Bali Island convert to electrical vehicle. The Table 2 show us the quantity of the vehicles in Bali by year. In this research, it only counts two wheels vehicle and four wheels vehicle in 2019. After the energy needed is calculated, to review if the Bali electricity systems, capacity and the planning of the systems are capable to accommodate the usage of electric vehicle.

Table 2: Quantity of several type vehicles (000 units)

\begin{tabular}{|c|c|c|c|c|c|c|}
\hline TYPE & 2014 & 2015 & 2016 & 2017 & 2018 & 2019 \\
\hline Bus & 7 & 7 & 8 & 8 & 9 & 9 \\
\hline Truck & 124 & 133 & 138 & 143 & 148 & 154 \\
\hline 2 wheels & 2,811 & 3,015 & 3,185 & 3,337 & 3,517 & 3,739 \\
\hline 4 wheels & 326 & 350 & 372 & 397 & 423 & 450 \\
\hline Total & 3,268 & 3,506 & 3,725 & 3,907 & 4,118 & 4,353 \\
\hline
\end{tabular}

\subsection{Economic Comparison}

This research will do the cost comparison between the cost of energy for conventional vehicle and electric vehicle. For the conventional vehicle, we can calculate the petroleum consumption for two wheels and four wheels vehicles. And for the electric vehicles we can find out the electric vehicle electric energy consumption for each two wheels vehicle and four wheels vehicle. In this paper, it is assumed to use solar PV independent power producer in house level to produce the electrical energy.

\subsection{Solar Energy}

Bali has big potential of solar energy. It might be a source of energy for the electric vehicle energy consumption. Solar energy is clean energy, this will help to sustain the tourisms industry in Bali that based on nature. Based on the study Bali has potential of solar energy about $98,738 \mathrm{GWh}$ per year, which mean that average $270 \mathrm{GWh}$ per day [2]. This might be enough for the electric energy requirement in Bali including electric vehicle energy requirement. It can create Bali 100\% renewable energy for domestic house consumption including the transportation [5]

\section{RESULTS AND DISCUSSION}

A study for the electrical vehicle energy consumption is: $33 \mathrm{Wh} / \mathrm{km}$ for the scooter $84 \mathrm{Wh} / \mathrm{km}$ for $123-165$ $\mathrm{Wh} / \mathrm{km}$ for 4 wheels vehicle [8]. In Indonesia, blue bird taxi operator has been using electrical vehicle, BYD and Tesla. For two wheels vehicle, Indonesia government had been promoting and supporting for two wheels vehicle production, and the specification reference is as Table 3 and Table 4. Additional information for the 
vehicle is available in the market.

Table 3: 4 Wheels electric vehicle energy consumption

\begin{tabular}{cccc}
\hline \multicolumn{1}{c}{ Type } & $\begin{array}{c}\text { Battery } \\
\text { Capacity }\end{array}$ & Distance & kWh/km \\
\hline BYD e6 & $80 \mathrm{kWh}$ & $400 \mathrm{~km}$ & $0.2 \mathrm{kWh} / \mathrm{km}$ \\
\hline Tesla Model X & $72.5 \mathrm{kWh}$ & $355 \mathrm{~km}$ & $0.2 \mathrm{kWh} / \mathrm{km}$ \\
\hline Hyundai Kona & $39.2 \mathrm{kWh}$ & $305 \mathrm{~km}$ & $0.13 \mathrm{kWh} / \mathrm{km}$ \\
\hline
\end{tabular}

Table 4: 2 Wheels electric vehicle energy consumption

\begin{tabular}{lccc}
\hline \multicolumn{1}{c}{ Type } & $\begin{array}{c}\text { Battery } \\
\text { Capacity }\end{array}$ & Distance & $\mathbf{k W h} / \mathbf{k m}$ \\
\hline HD Livewire & $15.5 \mathrm{kWh}$ & $234 \mathrm{~km}$ & $0.06 \mathrm{kWh} / \mathrm{km}$ \\
\hline Vespa Elettrica & $4.2 \mathrm{kWh}$ & $70-100 \mathrm{~km}$ & $0.042 \mathrm{kWh} / \mathrm{km}$ \\
\hline Gesit & $1.98 \mathrm{kWh}$ & $85-100 \mathrm{~km}$ & $0.022 \mathrm{kWh} / \mathrm{km}$ \\
\hline
\end{tabular}

From the electric vehicle manufacturer, we got the battery capacity and the distance with the capacity. We can calculate the average energy consumption of the electric vehicle. Table 3 shows 4 wheels car used for Blue Bird Taxi, a taxi operator in Indonesia and a new model of 4 wheels electric car from Hyundai in Indonesia. Two wheels motorbike, that is the motorbike promoted by Indonesia government. To calculate the average energy consumption (eq. 1), we need the assumption of average distance by type of car. We can use the assumption of car manufacturer for the service period, as shown in Table 5. Vehicle manufacturer set the period service or maintenance by distance and timing. In Table 5 we can see distance and timing for 2 wheels and 4 wheels vehicle. We can make assumption the daily average distance.

$$
\begin{array}{ll}
\text { Average Energy }=\frac{\text { Battery capacity }}{\text { dis } \tan c e} \\
\text { - Average energy } & : \mathrm{kWh} / \mathrm{km} \\
\text { - Battery } & : \mathrm{kWh} \\
\text { - Distance } & : \mathrm{Km}
\end{array}
$$

Table 5: Average distance assumption

\begin{tabular}{cccc}
\hline Type & $\begin{array}{c}\text { Time } \\
\text { (months) }\end{array}$ & Distance (km) & Avg Distance \\
\hline 4 wheels & 6 & 10,000 & $55.5 \mathrm{~km} /$ day \\
\hline 2 wheels & $2-3$ & $2000-3000$ & $33.3 \mathrm{~km} /$ day \\
\hline
\end{tabular}

From Table 6, we know that it requires 7,736,700 kWh per day for all the 2 and 4 wheels vehicles in Bali island. Figure 2 inform that Bali island require electric energy about 5,908 GWh, which mean that average $16,186,301 \mathrm{kWh}$ per day. If suddenly we convert all the vehicles into electric vehicle, the incremental of electric consumption per day is about $48.79 \%$.

Table 6: Energy Consumption Per Day

\begin{tabular}{lcccc}
\hline Type & Quantity & $\mathbf{k W h} / \mathbf{k m}$ & $\mathbf{K m} /$ day & $\mathbf{k W h} /$ day \\
\hline 4 wheels & 450,239 & 0.2 & 55.5 & $4,997,653$ \\
\hline 2 wheels & $3,738,803$ & 0.022 & 33.3 & $2,739,047$ \\
\hline & & & Total & $7,736,700$ \\
\hline
\end{tabular}

A good forecasting of electric vehicle growth in the market need to be done by the Bali government, electric energy provider (PT. PLN) and also the car manufacturer [9]. For electric energy provider, it is for the electric systems planning in Bali. Bali has 980 MW peak load in early of 2020 before the Covid19, the power generation is only $598 \mathrm{MW}$ installed and back up from Java systems about $380 \mathrm{MW}$. 


\subsection{Bali Electric Systems Planning}

Latest RUPTL 2019-2028 shows some development of the electrical systems in Bali. Table 7 is the forecast of the demand of electric energy in Bali. Forecast was based on energy economic growth, and the incremental of population, domestic usage and growth of business in Bali. But it might not cover the electric vehicle transformation. If the electric vehicle becomes popular, the growth will not be a linier line.

Table 7: Bali electric energy demand forecast [10]

\begin{tabular}{ccccc}
\hline Year & $\begin{array}{c}\text { Economic } \\
\text { Growth (\%) }\end{array}$ & $\begin{array}{c}\text { Sales } \\
(\mathbf{G W h})\end{array}$ & $\begin{array}{c}\text { Productio } \\
\mathbf{n}(\mathbf{G W h})\end{array}$ & $\begin{array}{c}\text { Peak } \\
\text { Load } \\
\text { (MW) }\end{array}$ \\
\hline 2019 & 5.29 & 5,549 & 5,585 & 932 \\
\hline 2020 & 5.17 & 5,866 & 6,180 & 982 \\
\hline 2021 & 6.08 & 6,284 & 6,007 & 1,049 \\
\hline 2022 & 6.00 & 6,717 & 7,057 & 1,120 \\
\hline 2023 & 5.91 & 7,168 & 7,526 & 1,194 \\
\hline 2024 & 5.89 & 7,634 & 8,010 & 1,269 \\
\hline 2025 & 5.77 & 8,110 & 8,503 & 1,349 \\
\hline 2026 & 6.23 & 8,658 & 9,071 & 1,435 \\
\hline 2027 & 6.17 & 9,230 & 9,663 & 1,528 \\
\hline 2028 & 6.11 & 9,828 & 10,281 & 1,625 \\
\hline Growth (\%) & 5.86 & 6.51 & 6.39 & 6.31 \\
\hline
\end{tabular}

Base on study that had been made, Bali has 354 MWe geothermal energy in Banyuwedang, Buleleng, Seririt Buleleng, Batukao Tabanan, Penebel Tabanan, Buyan-Bratan Buleleng, and Kintamani-Batur. Mini or micro hydro potential about $30 \mathrm{MW}$, wave energy in Nusa Penida about 10-50 MW, and solar energy about $100 \mathrm{MWp}$. Bali has quite a lot of potential renewable energy including the wave energy and also ocean thermal energy [10].

Table 8: Bali power generation planning

\begin{tabular}{lcccc}
\hline \multicolumn{1}{c}{ Type } & Location & $\begin{array}{c}\text { Capacity } \\
\text { (MW) }\end{array}$ & $\begin{array}{c}\text { Target } \\
\text { (COD) }\end{array}$ & Status \\
\hline Wave & $\begin{array}{c}\text { Nusa } \\
\text { Penida }\end{array}$ & 10.0 & 2020 & Delay \\
\hline Solar & Bali & 50.0 & 2020 & Delay \\
\hline Biomass & Bali & 0.9 & 2022 & Planning \\
\hline Waste & Bali & 15.0 & 2022 & Planning \\
\hline Geothermal & Bali & 65.0 & 2025 & Planning \\
\hline Solar/Wind & Bali & 50.0 & 2025 & Planning \\
\hline Total & & $\mathbf{1 9 0 . 9}$ & & \\
\hline
\end{tabular}

Table 8 is the power generation planning in Bali. All of them are considered as clean energy which is aligned with Bali government program for clean energy tourism area. Total of the planning is 190.9 MW until 2025. And most of the project will be delayed because of the covid-19 pandemic. There are still about $403 \mathrm{MW}$ still in study period for mini/micro hydro, geothermal, solar, wind, biomass and waste to energy. It looks like the planning is still align with the growth of the demand, but if suddenly electric vehicle become popular and get political incentive by government, the demand of electricity will increase exponential, and the planning will be not enough to cover the demand.

\subsection{Duck Curve Problem}

The growth of electric vehicle usage in several countries have side effect for daily load curve in electric systems. Normally, we travel or use the vehicle during the daytime, so most possibility that we electric vehicle will be charged during nighttime when we finish our daily business. This habit of charging will change the 
daily load curve. We know that the peak load of Bali is at $7.00 \mathrm{pm}$.

We know that it requires $7,736,700 \mathrm{kWh}$ per day for the electric vehicle usage. This energy demand requires Energy Management Systems, Demand Side Management or smart grid to separate the demand of energy it to 24 hours or when the load is low [11]. But it is a challenge to implement the demand side management, the electric systems in Bali might be not ready for it. If this daily energy requirement separate by only 4 hours at evening, that's mean the electric systems in Bali will increase 1934 MW. And if happen during the 07.00 PM that mean that the peak load in Bali will be 2,914 MW. The power factor in Bali will become low. This issue is called duck curve.

\subsection{Solar PV Independent Power Producer}

The study shown that electric vehicle usage will bring some affect those are the increase of the electricity demand sharply and duck curve issue. Electricity demand incremental could be solve by good forecasting about the incremental. The challenge is to predict when the electric vehicle will become popular or when most of the vehicle user will change their conventional fossil fuel vehicle to electric vehicle.

Duck curve issue might be solved by the demand side management. The concept is managing the when the user charges their electric vehicle. Demand side management motivate the user charge their electric vehicle when the electric systems load is low by giving some incentive such as lower cost [12]. Or in other way, the provider can set the higher cost for user to charge during the peak time. But the challenge, is PLN ready to apply the Demand Side Management? It required advance billing systems, and support by good IT and data systems.

The easier option is available. The option is the solar energy. We know that Bali has enough potential solar energy, and the solar energy technology is available in the market, it is mature, and the investment cost is decreasing while the trend is getting popular. But not the solar energy power station, it is every house to install the solar PV panel. At least the family who owns the electric vehicle, they need to install the solar PV panel to supply the energy. Table 9 shows the estimation of solar PV implementation by one of solar PV contractor in Jakarta. The capacity is $445 \mathrm{Wp}$ per panel. And it required 7 panel for $3 \mathrm{~kW}$ capacity. Each panel area is 2 meters square, and it required the 14 meters square.

Table 9: Solar PV implementation data

\begin{tabular}{cc}
\hline Capacity & $3,000 \mathrm{Watt}$ \\
Efficiency & $80 \%$ \\
\hline Net Capacity & $2,400 \mathrm{Watt}$ \\
\hline Electricity Production (Peak Hour) & $4 \mathrm{Jam}$ \\
\hline Electricity Production Per Day & $9,600 \mathrm{Wh}$ \\
\hline Electricity Production Per Year & $3,504,000 \mathrm{Wh}$ \\
\hline & $3,504 \mathrm{KWh}$ \\
\hline Electricity Price Incremental & $10 \%$ \\
\hline Investment Estimation & $16,000 \mathrm{IDR} / \mathrm{Watt}$ \\
\hline Total Investment & $48,000,000 \mathrm{IDR}$ \\
\hline
\end{tabular}

If we take example for the calculation by using Hyundai Kona electric vehicle. The battery capacity is $39.2 \mathrm{kWh}$, range $305 \mathrm{~km}$. We take the assumption daily travel is $55.5 \mathrm{~km}$. That means the user need to charge his car once is minimum 5 days. Electricity production per day is $9.6 \mathrm{kWh}$ by the solar PV. In 5 days, the solar $\mathrm{PV}$ panel can produce $48 \mathrm{kWh}$. By install 3,000 watts solar PV, 14 meters square, enough to produce the energy that require by the electric vehicle. Now how about the 2 wheels vehicle. The Gesit has $1.98 \mathrm{kWh}$, range from $85-100 \mathrm{~km}$. If we assume charging every 3 days. The battery is $1.98 \mathrm{kWh} .1$ panel 445 Watt can produce 4.27 $\mathrm{kWh}$ per 3 days. It is also enough for Vespa Elettrica, battery $4.2 \mathrm{kWh}$, range $70-100 \mathrm{~km}$.

\subsection{Economic Comparison}

Electric vehicle offers clean transportation and cost per km [13]. The cost needed for per km transportation can be calculated. Table $\mathrm{X}$ shown the cost per $\mathrm{km}$ for each type of vehicle. Gasoline for the fossil fuel in Table IX is using the Pertamina Pertalite at cost of Rp. 7,645 per liter. If using higher type, it will be higher. The EV is shown lower energy cost per km compare the conventional fossil fuel vehicle. If the electricity supply from independent solar PV, the investment cost is Rp. 48,000,000 for 25 years warranty operation. Assume the fossil fuel vehicle spend Rp. 250,000 per week, Rp. 13,000,000 per year. Payback period for solar PV investment is only 3.7 years. 
Table 10: Cost per km calculation

\begin{tabular}{cccc}
\hline \multicolumn{1}{c}{ Type } & Ratio & $\begin{array}{c}\text { Unit Cost } \\
\text { (Rupiah) }\end{array}$ & Cost/km \\
\hline 4 wheels fossil fuel & $10 \mathrm{~km} / \mathrm{litter}$ & 7,645 & 764.50 \\
\hline 2 wheels fossil fuel & $50 \mathrm{~km} / \mathrm{litter}$ & 7,645 & 152.90 \\
\hline 4 wheels EV & $0.2 \mathrm{kwh} / \mathrm{km}$ & $1,467.28$ & 293.46 \\
\hline 2 wheels EV & $0.042 \mathrm{kwh} / \mathrm{km}$ & 1.467 .28 & 61.61 \\
\hline
\end{tabular}

\section{CONCLUSIONS}

Electric vehicle is suitable in Bali, by its area, distance of travel and align with Bali green tourism program. Electric vehicle implementation will impact the electric systems in Bali, the challenge of forecasting the demand growth and planning of additional new power generation. Its also will impact the daily curve load. A model of forecasting the electricity demand. When the demand incremental will increase sharply must be answered in the future. Bali has big potential for the green energy, especially the solar energy. Electric vehicle cost per $\mathrm{km}$ is lower than conventional fossil vehicle. The price of electric vehicle is more expensive compare fossil fuel car. Electric vehicle price will decrease if it become more popular in the market. Solar PV technology is more and more efficient and advance. The investment cost will decrease slowly if more and more people using the solar PV. Independent solar PV to supply electricity to electric vehicle will be the easy way out if the grid does not have enough supply and for the duck curve problem.

\section{REFERENCES}

[1] DORCEC, L., PEVEC, D., VDOVIC, H., BABIC, J., PODOBNIK, V., "How do people value electric vahicle charging service? A gamified survey approach," Journal of Cleaner Production, v. 210, pp. 887897, 2019.

[2] BPS PROVINSI BALI, "Bali Province in Figures," In Report : BPS Provinsi Bali, Bali, 2020.

[3] DELGADO, J., FARIA, R., MOURA, P., DE ALMEIDA, A.T., "Impacts of plug-in electric vehicles in the portuguese electrical grid," Transportation Research Part D, v. 62, pp. 372-385, 2018.

[4] ANASTASIADIS, A.G., KONDYLIS, G. P., POLYZAKIS, A., VOKAS, G., "Effects of increased electric vehicles into a distribution network," Energy Procedia, v. 157, pp. 586-593, 2019

[5] GUNTHER, M., GANAL I., BOFINGER, S., "A 100\% renewable electricity scenario for java-bali grid," International Journal of Renewable Energy Development, v. 7, n. 1, pp. 13-22, 2018.

[6] GAY, D., ROGERS, T. SHIRLEY, R., "Small island developing states and their suitability for electric vehicles and vehicle-to-grid services," Utilities Policy, v. 55, pp. 69-78, 2018

[7] SAH, B.P., "Geo-enabled decision support system for potential clean energy mix for Bali, Indonesia," Energy Procedia, pp. 333-338, 2016.

[8] SAXENA, S., GOPAL, A., PHADKE, A., "Electrical consumption of two-, three- and four-wheel lightduty electric vehicles in India," Applied Energy, v. 115, pp. 582-590, 2014.

[9] PT. PLN (Persero), "Rencana usaha penyediaan tenaga listrik PT. PLN (Persero) 2019 - 2028," In Report : PT. PLN (Persero), Jakarta, 2019.

[10] SINUHAJI, A. R., "Potential Ocean Thermal Energy Conversion (OTEC) in Bali," KnE Energy, v. 1, pp. 5-12, 2013.

[11] FERRO, G., LAURERI, F.,. MINCIARDI, R., ROBBA, M., "An optimization model for electrical vehicles scheduling in a smart grid," Sustainable Energy: Grids and Networks, v. 14, pp. 62-70, 2018.

[12] FERRO, G., PAOLUCCI, M., ROBBA, M., "An optimization model for electrical vahicles routing with time of use energy pricing and partial recharging," IFAC-PapersOnLine, v. 51, n. 9, pp. 212-217, 2018.

[13] SHAUKAT, N., KHAN, B., ALI, S., MEHMOOD, C. , KHAN, J., FARID, J., MAJID, U., ANWAR, S., JAWAD, M., ULLAH, Z., "A survey on electric vehicle transportation within smart grid system," Renewable and Sustainable Energy Reviews, v. 81, pp. 1329-1349, 2018. 